\title{
SYNTHESIS OF $\mathrm{Ba}_{0.5} \mathrm{Sr}_{0.5} \mathrm{Co}_{0.8} \mathrm{Fe}_{0.2} \mathrm{O}_{3-\delta}$ FROM DIFFERENT PRECURSOR MATERIALS EMPLOYING MICROWAVE HEATING
}

\author{
S. Zeljkovic ${ }^{1, *}$, J. Penavin-Škundrić ${ }^{1}$, T. Ivas ${ }^{2}$, S. Vaucher $^{3}$ \\ ${ }^{1}$ University of Banja Luka, Faculty of Science and Mathematics, Mladena Stojanovića 2, \\ 78000 Banja Luka, Bosnia and Herzegovina \\ ${ }^{2}$ Nonmetallic Inorganic Materials, Department of Materials, ETH-Zurich, \\ Wolfgang-Pauli-Strasse 10, HCI G 530, CH-8093 Zurich, Switzerland \\ ${ }^{3}$ EMPA - Swiss Federal Laboratories for Materials Science and Technology, Advanced \\ Material Processing, Feuerwerkerstrasse 39, CH-3602 Thun, Switzerland
}

\begin{abstract}
Ba}_{0.5} \mathrm{Sr}_{0.5} \mathrm{Co}_{0.8} \mathrm{Fe}_{0.2} \mathrm{O}_{3-\delta}$ powders with perovskite structure have been synthesized from different mixtures of nitrate, oxide and carbonate precursors, irradiated in a microwave oven with $2.45 \mathrm{GHz}$ and various power outputs. The microwave synthesis was carried out in oxygen atmosphere. The effects of rapid microwave heating were evaluated mainly by comparing the state of materials before and after microwave exposure. Different precursors were evaluated according to their sensitivity to microwave field and toxicity of byproducts. The lower temperature and shorter time for $\mathrm{Ba}_{0.5} \mathrm{Sr}_{0.5} \mathrm{Co}_{0.8} \mathrm{Fe}_{0.2} \mathrm{O}_{3-\delta}$ synthesis with microwave irradiation might be ascribed to the activating and facilitating effect of microwave on solid phase diffusion. Microwave irradiation is proved to be a novel, time-saving and energy-efficient route to the synthesis of $\mathrm{Ba}_{0.5} \mathrm{Sr}_{0.5} \mathrm{Co}_{0.8} \mathrm{Fe}_{0.2} \mathrm{O}_{3-\delta}$ powder.
\end{abstract} nal heating.

Keywords: $\mathrm{Ba}_{0.5} \mathrm{Sr}_{0.5} \mathrm{Co}_{0.8} \mathrm{Fe}_{0.2} \mathrm{O}_{3-\delta}$, perovskite, synthesis, calcinations, conventio-

\section{INTRODUCTION}

$\mathrm{Ba}_{0.5} \mathrm{Sr}_{0.5} \mathrm{Co}_{0.8} \mathrm{Fe}_{0.2} \mathrm{O}_{3-\delta}(\mathrm{BSCF})$ mixed ionic electronic conductor with a cubic perovskite structure has recently attracted a great attention as a material in variety of progressive technologies.

BSCF was originally developed as a membrane permeable to oxygen by $50 \%$ substitution of $\mathrm{Sr}^{2+}$ cations in $\mathrm{SrCO}_{0.8} \mathrm{Fe}_{0.2} \mathrm{O}_{3-\delta}(\mathrm{SCF})$ with larger diameter $\mathrm{Ba}^{2+}$ cations. $\mathrm{BSCF}$, with respect to its structure, is characterized by a greater phase stability and higher oxygen vacance diffusivity than SCF $[1,2]$. In several studies it has been confirmed that $\mathrm{Ba}_{0.5} \mathrm{Sr}_{0.5} \mathrm{Co}_{0.8} \mathrm{Fe}_{0.2} \mathrm{O}_{3-\delta}$ shows a high performance not only as a membrane for oxygen but also as a membrane reactor for partial oxidation of methane and ethane into syngas [3, 4, 5]. In 2004, Shao and Haile [6] reported use of BSCF perovskite as cathode material for low-temperature solid oxide fuel cells (SOFC). Preliminary investigations were also made in the field of application of BSCF perovskite as adsorbent.
Synthesis of $\mathrm{Ba}_{0.5} \mathrm{Sr}_{0.5} \mathrm{Co}_{0.8} \mathrm{Fe}_{0.2} \mathrm{O}_{3-\delta}$ perovskite has so far mainly been performed by energy-inefficient and time-consuming methods such are combined citrate - EDTA complexing method [7] and solid state method [8].

Application of microwave heating began at the end of 1940s, more than 70 years after the development of Maxwell's theory of electromagnetic field in $1864[9,10,11]$. In addition to the application of microwaves in food preparation, the applications were also found in industrial applications such as drying of ceramics, paper, textile and adhesive [12, 13]. Recently, on the basis of the available literature and publications, it can be concluded that microwaves, due to the reduction of heating time, volumetric heating and energy savings, are more used for processing materials, including polymers, metals, semiconductors, biomaterials and perovskites [14].

The aim of presented research was to establish parameters of barium strontium cobalt iron oxide synthesis by microwaves with evaluation of possible application of various chemical compounds as precursors. 


\section{EXPERIMENT}

Selected oxide, carbonate and nitrate precursors were used as materials for the synthesis of BSCF ceramics (Table 1). Each of these precursors has a different sensitivity to microwave irradiation.

Thus carbonates of these elements have relatively low sensitivity to MW irradiation while oxides have important differences in terms of whether their magnetic (magnetite) or nonmagnetic (hematite) compounds. In the case of nitrates, we can talk about a great sensitivity to the microwave irradiation due to dipole momentum of these compounds and crystal water present in the structure in some cases. Replacement of cobalt carbonate with Co (II, III) oxide during the experiment was carried out in accordance with the intent of increasing the sensitivity of the precursor to microwave irradiation.

Table 1. Precursors for microwave heating assisted synthesis

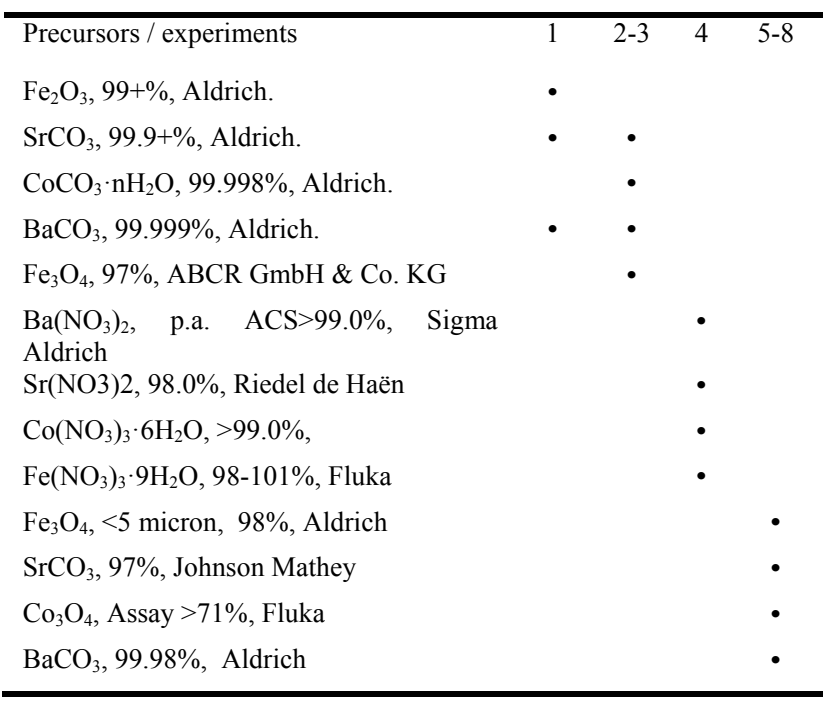

For cobalt carbonate hydrate TG, the analysis was performed to determine the content of cobalt in the material (adjustment is carried out in stoichiometric calculations).

The evaluation process of microwave assisted BSCF perovskite synthesis in the further consideration also involved type, quantity and toxicity of byproducts (gases).

The mass of the sample was $0.3 \mathrm{~g}$ in measurements $1-5$, then $0.9 \mathrm{~g}$ in measurement 6 and $0.5 \mathrm{~g}$ in measurements 7 and 8 . The change of the sample weight was done with the aim of evaluating its impact on the temperature. All the experiments were carried out under air atmosphere, with or without flow and with variable pressure.

In attempt to determine the effect of microwaves on an empty quartz carrier, it was observed that
25 minutes long irradiation induced no increase in temperature.

Precursors were mixed in a mortar for one hour, except for one measurement (with a mixture of hematite, $\mathrm{Sr}, \mathrm{Co}$ and $\mathrm{Ba}$ carbonate) when mixing was done in the mill with the Zirconia balls during 24 hours. During the experiments, the samples were located in the inner quartz shell. During the first experiment, the measurement was done without insulation, in the case of the second experiment - with a double quartz shell and, in all other experiments, with additional boron nitride insulation located in between the inner and outer quartz shell, all with the aim to provide an efficient thermal insulation of the sample. Boron nitride, used as an insulating layer, was pressed into the form of a ring and then sorted in a quartz shell.

Microwave heating was carried out in WR340 wave guide. Microwave generator with maximum power of $1.2 \mathrm{~kW}$ at $2.45 \mathrm{GHz}$ (Dipolar $\mathrm{AB}$, Skellefteå, Sweden) was directly connected to the wave guide. Incidence and reflected microwave power was monitored through the high power resistor (S-TEAM STHT, Bratislava, Slovakia).

For measuring of X-ray diffraction on the powders D5000 diffractometer with $\mathrm{Cu}-\mathrm{K} \alpha$ x-ray tube $(\lambda=154 \mathrm{~nm})$ and $\Theta-2 \Theta$ configuration was used. Measurements were performed in the range from $10^{\circ}$ to $100^{\circ}$ 2theta with $0.02^{\circ}$ step.

\section{RESULTS AND DISCUSSION}

Microwave assisted synthesis of the BSCF perovskite from hematite and $\mathrm{Sr}, \mathrm{Co}$ and $\mathrm{Ba}$ carbonate was unsuccessful. During the first measurement, the temperature of the sample after irradiation in the period of ca. 30 minutes has reached $450{ }^{\circ} \mathrm{C}$ which was not enough to form BSCF perovskite. XRD measurement performed on the resulting material showed that BSCF was not present. Visually, the material has changed color (darkened) and reduced its volume.

Synthesis of BSCF perovskite from magnetite and $\mathrm{Sr}, \mathrm{Co}$ and $\mathrm{Ba}$ carbonate was performed with a variable applied power (up to $600 \mathrm{~W}$ ) where the power was adsorbed up to $200 \mathrm{~W}$, in the presence of plasma. The sample was heated to $800{ }^{\circ} \mathrm{C}$ with the thermal jumps up to $1000{ }^{\circ} \mathrm{C}$ due to plasma overheating (Figure 1). The experiment was conducted in an atmosphere of air but with a closed valve. The inner quartz shell was colored purple (probably from the reaction of quartz with $\mathrm{Co}$ ). The produced material was later identified as BSCF by X-ray analysis (Figure 6-c). The sample was not fully crystallized and the highest peak intensity did not exceed 450 counts. 


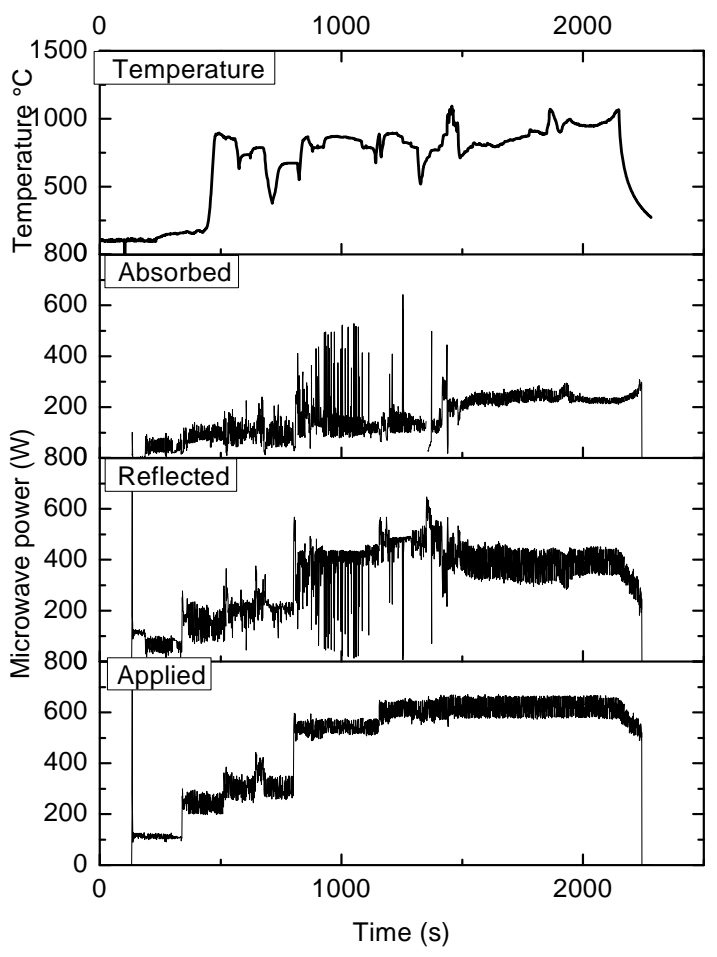

Figure 1. Temperature and energy diagram for measurement 2

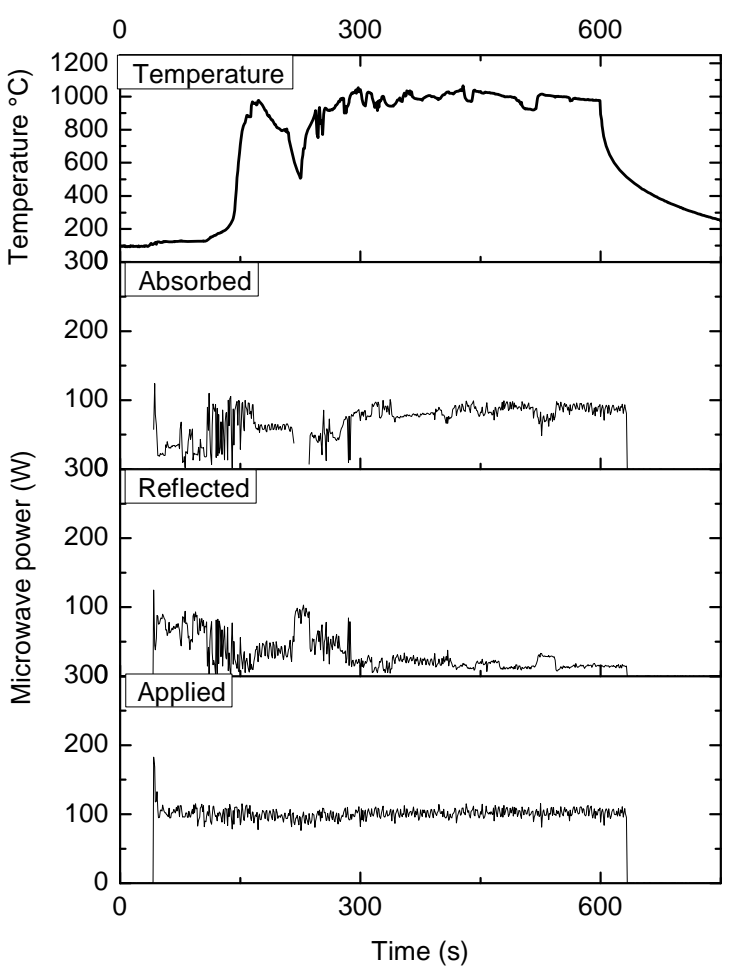

Figure 2. Temperature and energy diagram for measurement 3

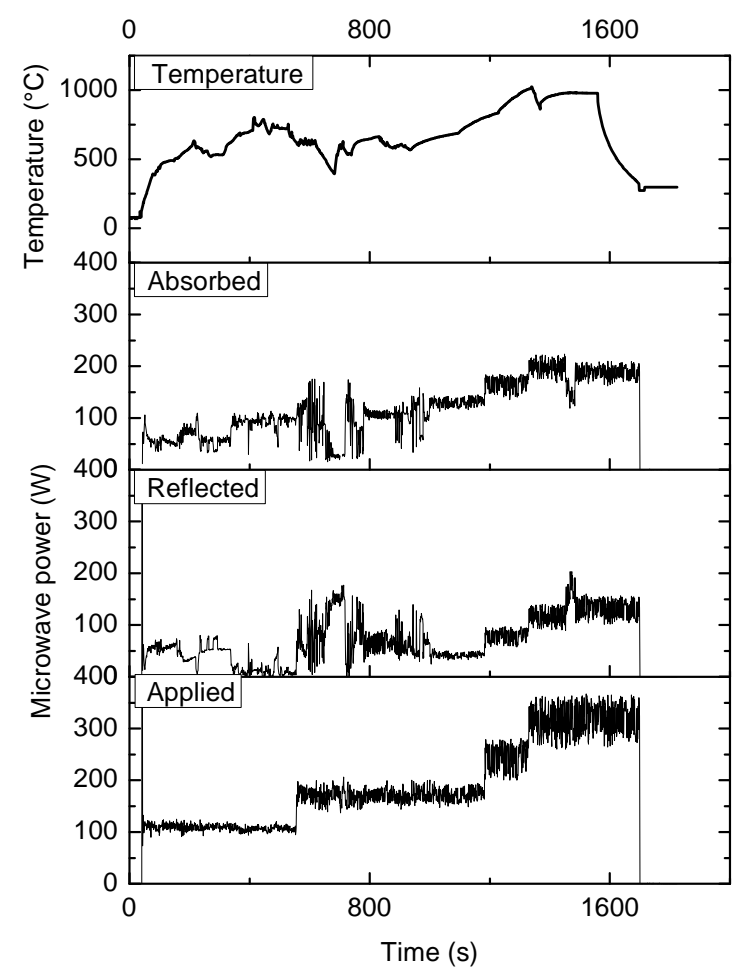

Figure 3. Temperature and energy diagram for measurement 4

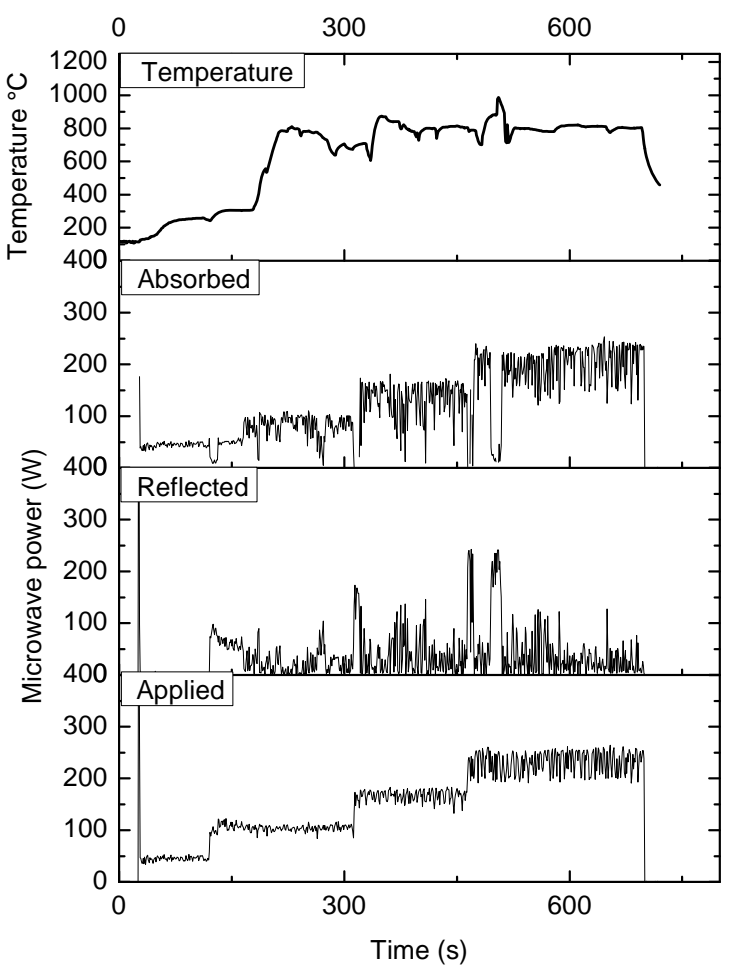

Figure 4. Temperature and energy diagram for measurement 5 
By application of variable pressure (in order to examine the effect on plasma), the sample was heated to $1000{ }^{\circ} \mathrm{C}$. The applied power did not exceed $100 \mathrm{~W}$ which was predominantly absorbed by the sample (Figure 2). The temperature of the sample without the presence of plasma was $200{ }^{\circ} \mathrm{C}$ higher than in the experiment without the insulation layer. The resulting material was stained dark with signs of melting at the top (where contact with plasma probably occurred). The inner quartz shell was partially colored purple (probably from Co). XRD of the resulting material has indicated well-defined peaks of BSCF material and well crystallized structure (Figure 6-a).

During the synthesis of BSCF perovskite from $\mathrm{Fe}, \mathrm{Sr}, \mathrm{Co}$ and $\mathrm{Ba}$ nitrates the microwave irradiation power was $300 \mathrm{~W}$ and the maximum temperature was around $1000{ }^{\circ} \mathrm{C}$. The pressure was changed in order to examine the effect on the presence of plasma and on the temperature. Temperatures around $1000{ }^{\circ} \mathrm{C}$ were achieved during the work under vacuum. At the temperature diagram, after termination of the microwave irradiation, a rapid change in temperature was observed, having indicated the presence of plasma above the material (Figure 3). The resulting material was dyed purple (the vertical wall of the inner quartz sample holder), white (bottom) and red (center). This certainly can be partially explained by poor mixing of nitrate precursors and their separate and radical evaporation. On the X-ray diffractogram of the resulting materials two characteristic peaks of BSCF were indentified. The sample was poorly crystalline but the results testified a possible microwave synthesis of the BSCF ceramics from nitrate precursors even in the case of an insufficient mixing (Figure 6-e). Subsequently, for a more effective mixing, the nitrate sample was dissolved in the minimum amount of water. Due to the strong evaporation of gases during the heating, the experiment was terminated.

During the synthesis of BSCF perovskite from magnetite, Co oxide, Sr carbonate and Ba carbonate, the achieved temperature was $800{ }^{\circ} \mathrm{C}$ with $100 \mathrm{~W}$ of applied power. In average, the temperature was not increased significantly even when used power was up to $300 \mathrm{~W}$ (Figure 4). There were no indications of plasma presence.

On the XRD of calcined material, two peaks characteristic for BSCF perovskite can be identified (Figure 6-d).

With the intention of evaluating the effect of precursors mass (magnetite, Co oxide, Sr carbonate and $\mathrm{Ba}$ carbonate) on the temperature, $0.9 \mathrm{~g}$ of sample was heated in a three-part experiment. In the first part of experiment the material was heated to $800{ }^{\circ} \mathrm{C}$ with $100 \mathrm{~W}$ of applied power. At $900{ }^{\circ} \mathrm{C}$ plasma was observed and the temperature was increased up to $1000{ }^{\circ} \mathrm{C}$. With increasing strength of the applied microwave irradiation it has become very difficult to control the microwave field and temperature. Most of the applied energy was reflected. The same material was re-heated under air with $150 \mathrm{~W}$ and $100 \mathrm{~W}$ of applied power. Problems with the microwave field control have continued and the maximum measured temperature was $600{ }^{\circ} \mathrm{C}$. During the third consecutive warm-up (Figure 5), the material has reached an average temperature of $900{ }^{\circ} \mathrm{C}$. Applied power of $100 \mathrm{~W}$ was mainly absorbed by the sample. The material was heated in the absence of the air flow. Introduction of air flow generated the advent of plasma. Except in the presence of plasma, the temperature was uniform and stable. XRD of the resulting material has indicated well-defined peaks of BSCF material and well crystallized structure (Figure 6-b).

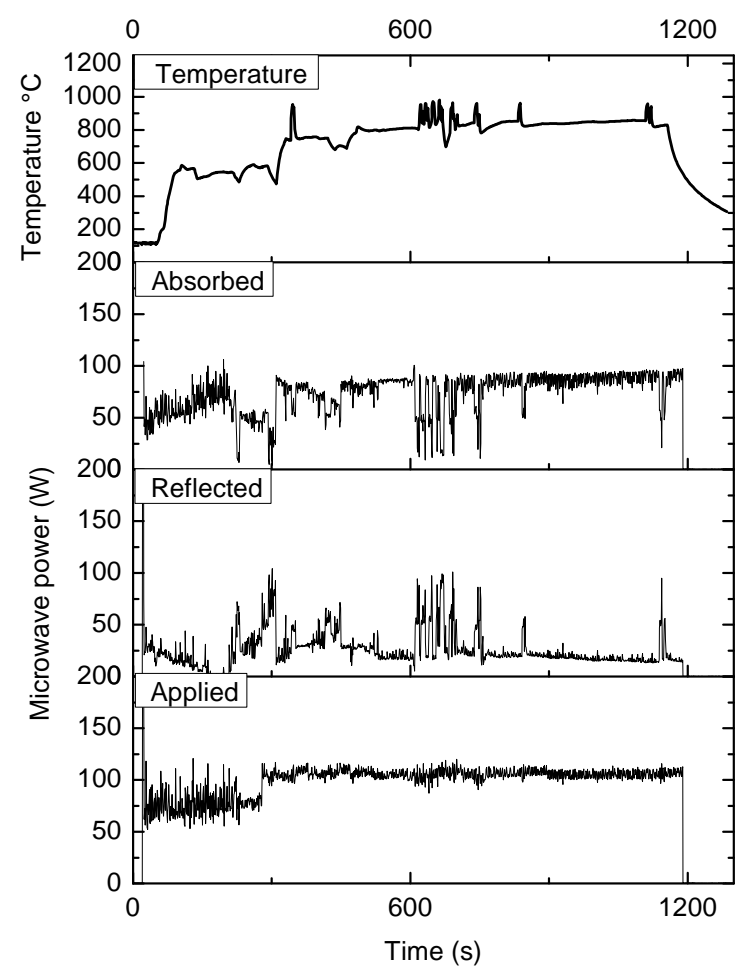

Figure 5. Temperature and energy diagram for measurement 6

The next experiment was carried out without the air flow. The microwave irradiation power first was $100 \mathrm{~W}$ until the temperature stabilized at 280 ${ }^{\circ} \mathrm{C}$, and then $150 \mathrm{~W}$ until the temperature stabilized at $700{ }^{\circ} \mathrm{C}$ and finally with $200 \mathrm{~W}$ in cca. 20 minutes. The maximum temperature was about $850{ }^{\circ} \mathrm{C}$. During the cooling, it was observed that it was possible to maintain a relatively high temperature with the applied power of $100 \mathrm{~W}$ (Figure 7). XRD of the resulting material indicated the presence of three peaks 
characteristic for BSCF perovskite, and poorly crystallized structure (Figure 6-f).

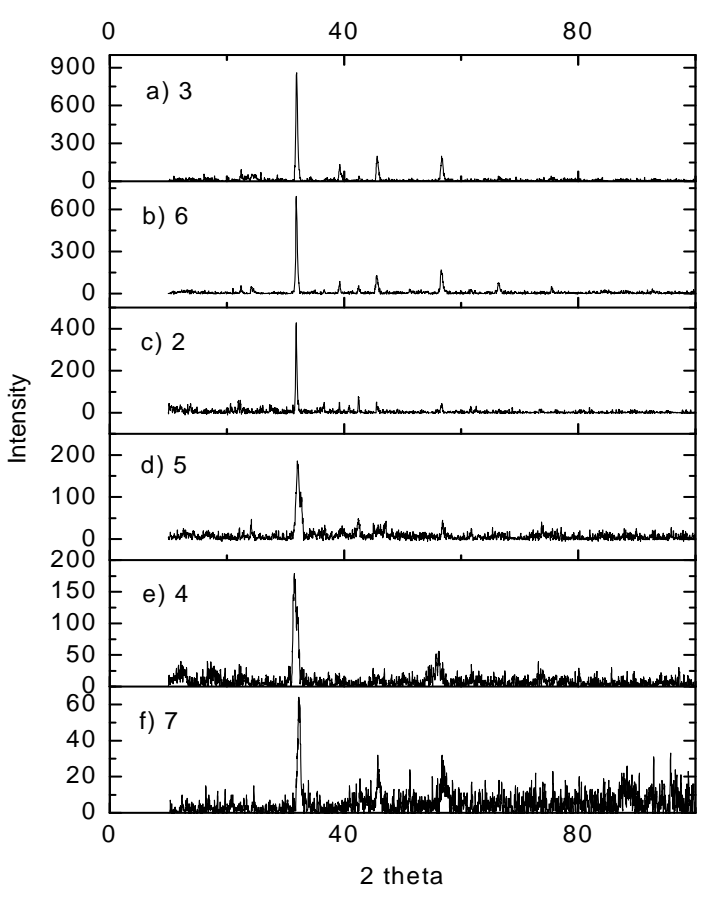

Figure 6. XRD diagrams of resulting materials of measurement 2,3,4,5,6 and 7

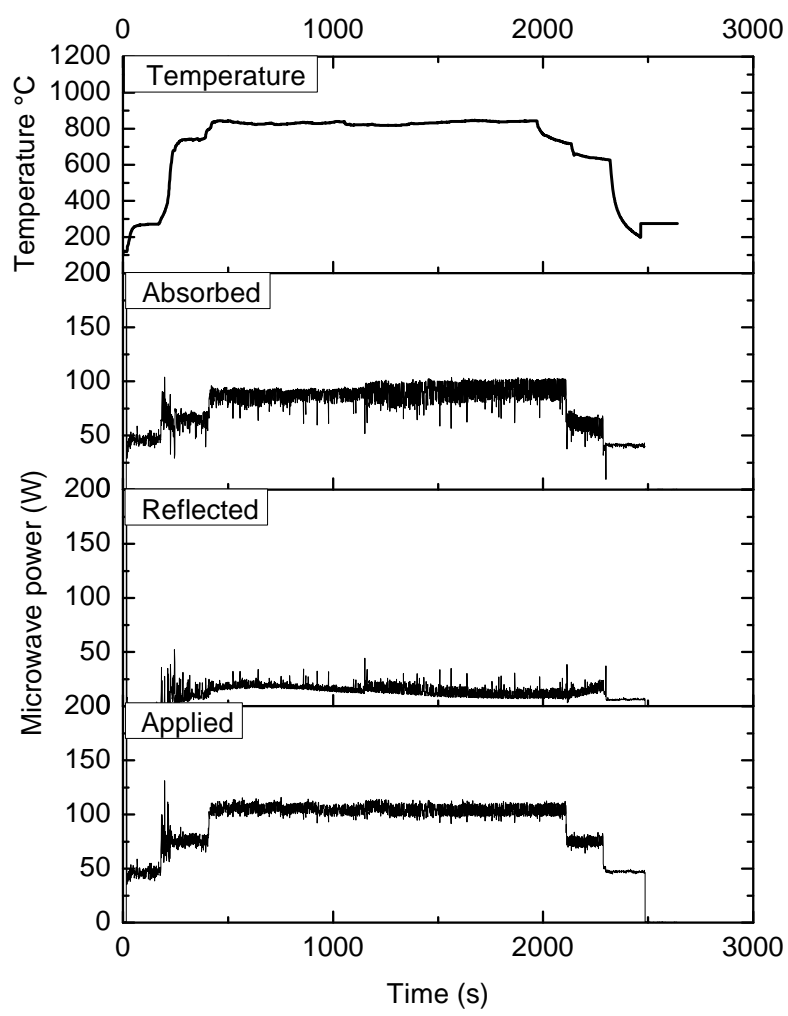

Figure 7. Temperature and energy diagram for measurement 7

In the final experiment, it was again noted that with $100 \mathrm{~W}$ of applied power it was not possible to heat the sample to a temperature higher than $200^{\circ} \mathrm{C}$. Some time after application of $150 \mathrm{~W}$, there were several indications of plasma. The increase in power from $150 \mathrm{~W}$ to $200 \mathrm{~W}$ did not lead to a radical increase in the temperature. With $100 \mathrm{~W}$, applied at the beginning of the experiment, the temperature did not exceed $200{ }^{\circ} \mathrm{C}$, while the same power was responsible for the temperature around $700{ }^{\circ} \mathrm{C}$ at the end of experiment (Figure 8).

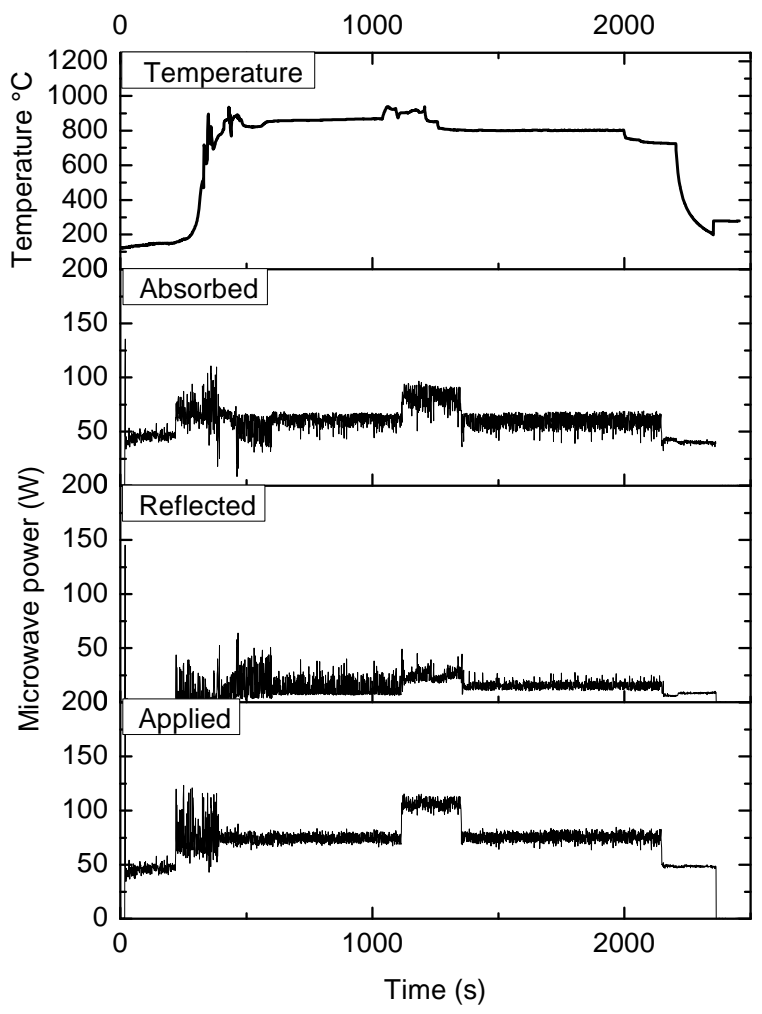

Figure 8. Temperature and energy diagram for measurement 8

\section{CONCLUSIONS}

Microwave assisted synthesis of perovskitetype oxides has proved to be efficient and economical in the several previous studies. The presented results are a positive evidence of interaction of different precursors with microwave field, all with the aim of producing BSCF perovskite. In the process of synthetic route testing it was concluded as follows:

\section{The influence of precursor}

Chemicals used as precursors in the synthesis process have different sensitivity to microwave irradiation. Thus, hematite $\left(\mathrm{Fe}_{2} \mathrm{O}_{3}\right)$ showed little sensitivity, carbonates of $\mathrm{Ba}, \mathrm{Sr}, \mathrm{Co}$ and $\mathrm{Fe}$ moderate sensitivity and nitrates of these elements, as well as 
magnetite, a very high sensitivity to the effects of magnetic field. Related to this is the fact that the synthesis of BSCF perovskite from hematite, $\mathrm{Sr}, \mathrm{Co}$ and $\mathrm{Ba}$ carbonate failed in terms of production BSCF perovskite. Replacement of hematite with magnetite in the precursor mixture yielded positive results with the satisfactory purity of the synthesized perovskite. Synthesis from nitrate precursors has, apart from very poor mixing of the precursors, given good results in terms of BSCF perovskite occurrence. During the intense heating, nitrates tend to develop large amounts of nitrogen oxides and water. Toxicity and explosiveness that occurs due to a sudden release of these gases is the key (unfavorable) reason why the work based on the nitrate precursor is not recommended. The attempt to dissolve small amounts of nitrate in water (for a better mixing) produced even less favorable results. The oxides were generally easier to handle in a microwave oven, relative to the nitrates. When compared to nitrates, during the thermal decomposition, they do not release large amounts of gas.

Therefore, magnetite, Co (II, III) oxide, $\mathrm{Sr}$ carbonate and $\mathrm{Ba}$ carbonate can be recommended as the precursors for the microwave assisted synthesis of BSCF. These materials possess the optimal sensitivity to the microwave field with no release of toxic byproducts.

\section{The effect of specimen mass and insulation}

During the absorption of microwave irradiation, thermal response depends solely on the precursors sensitivity. However, achieving and maintaining the temperature depends also on the mass of the sample and thermal isolation of the same. Thus, the measurement 6 showed that the increase in weight of the sample from $0.3 \mathrm{~g}$ to $0.9 \mathrm{~g}$ has lead to an increase in the maximum temperature from $100{ }^{\circ} \mathrm{C}$ to 200 ${ }^{\circ} \mathrm{C}$, depending on the other parameters. The instrument has no capacity for work with a sample of over $0.9 \mathrm{~g}$.

Insulation of the sample, made of boron nitride, also had a positive impact in terms of increasing the temperature of the sample.

The influence of MW power and the atmosphere

It was confirmed, through the experiments, that the examined materials possess a unique capacity of adsorption of microwave energy and that any excessive increase in microwave power did not provide an adequate thermal response. Thus the measurement number 2 showed that regardless of the ap- plied power, the absorbed power did not exceed 200 $\mathrm{W}$. The rest of the energy was reflected, or was simply heating the metal base of the instrument. This is even clearer in the result of measurements no. 8 where the increase of applied power from $50 \mathrm{~W}$ to $100 \mathrm{~W}$ did not affect the temperature of the sample. Increment of the applied power was not absorbed by the sample.

It was also observed that the increase in the applied microwave power increased the potential of plasma occurrence around the sample. Apart from the applied force, the plasma phenomenon was largely dependent on the atmosphere around the sample. The atmosphere of air (rich in oxygen) was very sensitive to the appearance of plasma. In general, the effect of plasma on the material can be positive, as well as negative. Since plasma appears in the surrounding excited atmosphere, it leads to an increase in the temperature of the atmosphere, reduction of the field strength adsorbed by the sample and consequently reduces the temperature of the deeper layers of the sample. In the case of a smaller mass (the kind used in the majority of the experiments) the emergence of plasma also had positive effects, mainly through an indirect heating.

\section{REFERENCES}

[1] Z. Shao, W. Yang, Y. Cong, H. Dong, J. Tong, G. Xiong, Investigation of the permeation behavior and stability of a $\mathrm{Ba}_{0.5} \mathrm{Sr}_{0.5} \mathrm{Co}_{0.8} \mathrm{Fe}_{0.2} \mathrm{O}_{3-\delta}$ oxygen membrane, J. Membr. Sci.172 (2000) 177-188.

[2] H. Wang, Y. Cong, W. Yang, , J. Membr. Sci. 210 (2002) 259-271.

[3] Z. Shao, G. Xiong, H. Dong, W. Yang, L. Lin, Synthesis, oxygen permeation study and membrane performance of a $\mathrm{Ba}_{0.5} \mathrm{Sr}_{0.5} \mathrm{Co}_{0.8} \mathrm{Fe}_{0.2} \mathrm{O}_{3-\delta}$ oxygen-permeable dense ceramic reactor for partial oxidation of methane to syngas, Sep. Purif. Technol. 25 (2001) 97-116.

[4] H. Wang, Y. Cong, W. Yang, Investigation on the partial oxidation of methane to syngas in a tubular $\mathrm{Ba}_{0.5} \mathrm{Sr}_{0.5} \mathrm{Co}_{0.8} \mathrm{Fe}_{0.2} \mathrm{O}_{3-\delta}$ membrane reactor, Catal. Today, 82 (2003) 157-166.

[5] H. Wang, Y. Cong, W. Yang, Partial oxidation of ethane to syngas in an oxygen-permeable membrane reactor, J. Membr. Sci. 209 (2002) 143152.

[6] Z. Shao, S.M. Haile, A High Performance Cathode for the Next Generation Solid-Oxide Fuel Cells, Nature 431 (2004) 170-173.

[7] A. Yan, M. Cheng, Y. Dong, W. Yang, V. Maragou, S. Song, P. Tsiakaras, Investigation of a $\mathrm{Ba}_{0.5} \mathrm{Sr}_{0.5} \mathrm{Co}_{0.8} \mathrm{Fe}_{0.2} \mathrm{O}_{3-\delta}$ based cathode IT-SOFC: I. 
The effect of $\mathrm{CO}_{2}$ on the cell performance, Appl. Catal. B, 66 (2006) 64-71.

[8] S. Zeljković, J. Penavin Škundrić, T. Ivas, Synthesis and characterization of selected BSCF ceramics of the perovskite type produced by conventional heating, Proceedings of „Contemporary materials“ (2010) 259-277.

[9] H. Sobol, K. Tomiyasu, Milestones of microwaves, IEEE T. Microw. Theory, 50 (2002) 594611.

[10] J. M. Osepchuk, Microwave power applications, IEEE T. Microw. Theory, 32 (1984) 12001224.
[11] A.W. Guy, History of biological effects and medical applications of microwave energy, IEEE T. Microw. Theory, 32 (1984) 1182-1200.

[12] D. F. Stein, "Microwave Processing of Materials", Cometee on Microwave Procesing of Materials, National Materials Advisory Board (1994).

[13] D. E. Clark, W. H. Suton, Microwave Processing of Materials, Annu. Rev. Mater. Sci., 26 (1996) 299-331.

[14] S. Zeljković, S. Vaucher, J. Penavin-Škundrić, T. Ivas, Evaluation of Microwave heating for the synthesis and sintering of $\mathrm{La}_{0.7} \mathrm{Sr}_{0.3} \mathrm{FeO}_{3+\delta}$ perovskite composition, Proceedings of 38th IOCMM (2006) 563-568.

$\operatorname{soc} 3$

\section{СИНТЕЗА ВА $0.5 \mathrm{SR}_{0.5} \mathrm{CO}_{0.8} \mathrm{FE}_{0.2} \mathrm{O}_{3-\Delta}$ ИЗ РАЗЛИЧИТИХ ПРЕКУРСОРА МИКРОВАЛНИМ ЗАГРИЈАВАЮЕМ}

Сажетак: $\mathrm{Ba}_{0.5} \mathrm{Sr}_{0.5} \mathrm{Co}_{0.8} \mathrm{Fe}_{0.2} \mathrm{O}_{3-\delta}$ пудери са структуром перовскита синтетизовани су из различитих мјешавина нитратних, оксидних и карбонатних прекурсора ирадијацијом у микровалној пећници на $2.45 \mathrm{GHz}$ уз различите вриједности излазне снаге. Микровална синтеза је изведена у атмосфери кисика. Ефекти рапидног микровалног загријавања углавном су евалуирани поређењем стања материјала прије и након изложености микроваловима. Различити прекурсори евалуирани су с обзиром на њихову осјетљивост на микровално зрачење и токсичност нуспродуката.

Нижа температура и краће вријеме за $\mathrm{Ba}_{0.5} \mathrm{Sr}_{0.5} \mathrm{Co}_{0.8} \mathrm{Fe}_{0.2} \mathrm{O}_{3-\delta}$ синтезу са микровалним зрачењем могу се приписати активационом и олакшавајућем ефекту микровалова на дифузију у чврстој фази. Микровална ирадијација се доказала као нова, брза и енергетски ефикасна метода за синтезу $\mathrm{Ba}_{0.5} \mathrm{Sr}_{0.5} \mathrm{Co}_{0.8} \mathrm{Fe}_{0.2} \mathrm{O}_{3-\delta}$ пудера.

Кључне ријечи: $\mathrm{Ba}_{0.5} \mathrm{Sr}_{0.5} \mathrm{Co}_{0.8} \mathrm{Fe}_{0.2} \mathrm{O}_{3-\delta}$, перовскит, синтеза, микровално загријавање. 